\title{
Persepsi Guru dan Peserta Didik terhadap Proses Pembelajaran Fisika Berdasarkan Kurikulum 2013
}

\author{
*1Melkianus Suluh, ${ }^{2}$ Jumadi \\ 1)STKIP Weetebula, Program Studi Pendidikan Fisika, Jl. Mananga Aba, Sumba \\ Barat Daya-NTT, Indonesia \\ 2)Universitas Negeri Yogyakarta, Indonesia \\ Email:smelkieinstein@gamil.com
}

$\begin{array}{ll}\text { ARTICLE INFO } & \text { ABSTRACT } \\ \text { Article history } & \text { [Title: Perception Of Teachers And Students On The Physical Learning Process } \\ \text { Received: March } 2019 & \text { Based On Curriculum 2013] This study aims to determine: (1) the perception of physics } \\ \text { Revised: April } 2019 & \text { teachers to apply a scientific approach, (2) the perceptions of students on the physics } \\ \text { Accepted: May } 2019 & \text { learning process carried out by teachers, (3) the relationship between students' } \\ \text { Published: June 2019 } & \begin{array}{l}\text { perceptions and the ability of teachers to carry out physics-based learning scientific } \\ \text { approach. This research is a survey research using a descriptive correlational approach. }\end{array} \\ \text { Keywords } & \text { The research sample included 18 physics teachers and 494 students spread across } 10 \\ \text { Scientific Approach; } & \text { Public High Schools in Yogyakarta City which were taken using a purposive sampling } \\ \text { Perception; } & \text { technique. Data collection uses questionnaires from teachers and students and } \\ \text { Teacher Ability } & \text { observation sheets. The analysis technique uses descriptive analysis and Spearman } \\ & \text { correlation analysis. Research Results (1) The teacher has a very positive perception of } \\ & \text { the implementation of a scientific approach in scientific learning; (2) Students give a } \\ \text { positive response to the process of physics learning carried out by the teacher; (3) There } \\ \text { is a positive and significant relationship between the perceptions of students and the } \\ \text { ability of teachers to carry out physics learning based on the scientific approach. }\end{array}$

\section{INFO ARTIKEL}

Sejarah Artikel

Dikirim: Maret 2019

Direvisi: April 2019

Diterima: Mei 2019

Dipublikasi: Juni 2019

Kata kunci

Pendekatan Ilmiah;

Persepsi;

Kemampuan Guru;

\section{ABSTRAK}

Penelitian ini bertujuan untuk mengetahui untuk mengetahui persepsi guru dan peserta didik terhadap proses pembelajaran fisika berdasarkan Kurikulum 2013. Aspek-aspek yang diukur dalam penelitian ini adalah: (1) Persepsi guru fisika menerapkan pendekatan ilmiah (scientific approach), (2) persepsi peserta didik terhadap proses pembelajaran fisika yang dilaksanakan guru, (3) hubungan antara persepsi peserta didik dengan kemampuan guru dalam melaksanakan pembelajaran fisika berbasis pendekatan ilmiah (scientific approach). Penelitian ini merupakan penelitian survei dengan menggunakan pendekatan deskriptif korelasional. Sampel penelitian meliputi 18 guru fisika dan 494 peserta didik yang tersebar pada 10 SMA Negeri di Kota Yogyakarta yang diambil menggunakan teknik purposive sampling. Pengumpulan data menggunakan instrumen angket guru dan peserta didik, dan lembar pengamatan. Teknik analisis menggunakan analisis deskriptif dan analisis korelasi Spearman. Hasil penelitian menunjukkan bahwa: (1) Guru memiliki persepsi yang sangat positif diterapkannya pendekatan ilmiah (scientific approach) dalam pembelajaran fisika; (2) Peserta didik memberikan tanggapan yang positif terhadap proses pembelajaran fisika yang dilaksanakan guru; (3) Terdapat hubungan yang positif dan signifikan antara persepsi peserta didik dengan kemampuan guru melaksanakan pembelajaran fisika berbasis pendekatan ilmiah (scientific approach).

How to Cite this Article? Suluh, M \& Jumadi. (2019). Persepsi Guru dan Peserta Didik terhadap Proses Pembelajaran Fisika Berdasarkan Kurikulum 2013. Jurnal Penelitian dan Pengkajian Ilmu Pendidikan: e-Saintika, 2(2), 62-74. 


\section{PENDAHULUAN}

Salah satu hal mendasar dari perubahan kurikulum 2013 adalah diterapkannya pendekatan ilmiah atau scientific approach dalam setiap proses pembelajaran pada setiap satuan dan jenjang pendidikan (Permendikbud No. 65 Tahun 2013) di mana pembinaan sikap, pengetahuan dan keterampilan menjadi pusat tujuan pembelajaran untuk mengembangkan manusia Indonesia seutuhnya (Suluh, 2018). Penetapan pendekatan ilmiah (scientific approach) pada kurikulum 2013 tidak terlepas dari landasan pengembangan dan tujuan dari perubahan kurikulum, hal ini memberikan gambaran bahwa setiap kurikulum memiliki karakteristik yang berbeda.

Penggunaan pendekatan ilmiah (scientific approach) dalam proses pembelajaran pada pada hakikatnya bukan merupakan pendekatan yang baru, dalam kurikulum tahun 1980-1983 dijabarkan dalam tahapan pendekatan keterampilan proses yang meliputi tahapan (1) mengamati atau observasi, (2) mengklasifikasikan data/informasi, (3) mencari hubungan ruang/waktu/kejadian-meramal, (4) membuat hipotesis, (5) merencanakan eksperimen/penelitian, (6) Menginterpretasikan atau menafsirkan data (7) Menyusun kesimpulan sementara dan (8) mengkomunikasikan (Kemendiknas, 2010). Selain itu, tahapan pendekatan ilmiah (scientific approach) juga tergambar dalam Kurikulum 2006. Kurikulum tersebut menyatakan bahwa (Depdiknas, 2007) "Pembelajaran IPA hendaknya dilaksanakan secara inkuiri ilmiah (scientific inquiry) untuk menumbuhkan kemampuan berpikir, bekerja dan bersikap ilmiah serta mengkomunikasikannya sebagai aspek penting kecakapan hidup', dan 'pembelajaaran fisika dilaksanakan secara inkuiri ilmiah untuk menumbuhkan kemampuan berpikir, bekerja, dan bersikap ilmiah serta berkomunikasi sebaggai salah satu aspek penting kecakapan hidup". Dengan demikian, guru tidak mengalami kesulitan dalam menerapkan pendekatan ilmiah, teruma adalam pembelajaran fisika, hal ini karena konsep pendekatan ilmiah, dan bagaimana memperlajari fisika memiliki kesamaan, yakni menggunakan pembukian secara ilmiah.

Permasalahan yang muncul dari penerapan kurikulum baru adalah menyamakan persepsi antara pembuat kurikulum dan pengguna kurikulum. Pemerintah sebagai pembuat dan pengmabil kebijakan tentu memiliki pendangan tersendiri tentang perlunya perubahan kurikulum dengan menerapkan kurikulum baru. Namun, penerapan kurikulum baru yang mengendepankan bentuk pembelajaran yang berbeda keberhasilannya sangat diperngaruhi oleh tanggapan dan persepsi guru. Hal ini disampaikan oleh Middleton (1999) bahwa berhasil tidaknya implementasi kurikulum yang diperbarui cenderung ditentukan oleh persepsi atau keyakinan yang dimiliki oleh tenaga pengajar atau guru (Puskur, 2008). Pernyataan ini didukung oleh hasil penelitian yang dilakukan Reh Malem Ginting (2008) yang menunjukan adanya hubungan yang positif dan signifikan antara persepsi guru terhadap perubahan kurikulum dengan kinerja guru. Dari kedua pernyataan tersebut, dapat diartikan bahwa berhasil tidaknya implementasi kebijakan pendidikan yang baru sangat ditentukan oleh sudut pandang atau persepsi yang dimiliki guru. Persepsi tentang bagaimana guru melihat perubahan kurikulum sebagai upaya pembenahan pendidikan. 
Salah satu upaya yang dilakukan pemerintah dalam menyatukan beragam persepsi dikalangan guru dan pemerhati pendidikan dengan melakukan kegiatan pelatihan-pelatihan dan sosialisasi. Tujuannya menyatukan beragam persepsi yang ada, dan memberikan informasi terkait tujuan perubahan kurikulum, serta meningkatkan pengetahuan guru terhadap paradigma pembelajaran yang baru.

Salah satu aspek yang dapat digunakan dalam menilai keberhasilan dari kegiatan pembelajaran fisika adalah dengan menilai atau menganalisis tanggapan yang diberikan siswa terkait proses pembelajaran yang dilakukan guru. Dengan melihat tanggapan yang diberikan siswa, dapat diketahui keberhasil proses pembelajaran. Sebagaimana yang disampiakan Kunandar (2013), bahwa salah satu cara yang bisa digunakan untuk mengetahui kekurangan dan kelemahan dalam proses pembelajaran di samping dari hasil belajar peserta didik, juga dapat diperoleh dari respon atau tanggapan peserta didik ketika proses pembelajaran berlangsung. Hal ini juga dikemukan oleh Carvalho (2011) dengan menyatakan: "Student perceptions about how teachers implement the curriculum can function as a starting point for promoting teachers' reflection and, as such, to revise and to develop new conceptions and beliefs in accordance with curricular goals". Sedangkan menurut Struyven, dkk dalam Carvalho (2011) “...student perception about teacher practice plays an important role in the individual student's personal involvement with learning".

Dengan melihat sejarah kurikulum pendidikan Indonesia, tuntutan kurikulum 2013, dan konsep pembelajaran fisika, peneliti tertarik untuk mencoba melakukan penelitian terkait persepsi guru dengan diterapkannya pendekatan ilmiah dan persepsi peserta didik terhadap proses pembelajaran yang dilakukan guru, serta hubungan antara persepsi peserta didik dengan kemampuan guru menerapkan pendekatan ilmiah dalam proses pembelajaran.

\section{METODE}

Penelitian ini merupakan survei dengan pendekatan deskriptif korelasional. Penelitian ini dilaksanakan di SMA Negeri Kota Yogyakarta Provinsi Daerah Istimewa Yogyakarta. Populasi dari penelitian ini adalah guru fisika yang mengajar pada kelas X dan kelas XI serta peserta didik kelas X dan kelas XI. Sampel guru diambil dengan teknik purposive sampling yang berjumlah 18 orang. Peserta didik yang menjadi responden berjumlah 494 yang diambil dari salah satu kelas diajar oleh guru yang menjadi subyek penelitian.

Teknik pengumpulan data dilakukan dengan mengunakan instrumen angket, dan instrumen observasi. Instrumen angket terdiri dari instrumen angket angket persepsi guru dan instrumen angket persepsi peserta didik. Angket persepsi guru digunakan untuk mengetahui pandangan guru terhadap pelaksanaan pendekatan ilmiah (scientific approach) dalam pembelajaran fisika yang terdiri dari empat kategori jawaban, yakni: selalu (4), kadang-kadang (3), jarang (2), dan tidak pernah (1). Pada instrumen ini peneliti juga hendak mengetahui latar belakang peneliti yang menjadi subyek penelitian. Berikut kisi-kisi angket yang diberikan kepada guru fisika yang menjadi subyek penelitian. 
Tabel 1. Kisi-Kisi Angket Persepsi Guru Terhadap Penerapan Pendekatan Ilmiah Dalam Pembelajaran Fisika

\begin{tabular}{ll}
\hline Indikator Penilaian & Nomor Soal \\
\hline Penerimaan & $1-10$ \\
Pelaksanaan Pembelajaran & $11-22$ \\
\hline
\end{tabular}

Pada Tabel 2 berikut ditampilkan kisi-kisi angket persepsi peserta didik. Angket persepsi peserta didik mengunakan empat pilihan jawaban, yakni: sering (4), kadang-kadang (3), jarang (2), dan tidak pernah (1).

Tabel 2. Kisi-Kisi Angket Persepsi peserta didik

\begin{tabular}{lll}
\hline Aspek Yang Diukur & Indikator & Nomor Soal \\
\hline Persepsi peserta didik terhadap & Pendahuluan. & $1-5$ \\
pelaksanaan pembelajaran berbasis & Mengamati. & $6-11$ \\
scientific approach yang dilakukan guru. & Menanya. & $12-15$ \\
& Mengumpulkan informasi. & $16-21$ \\
& Mengasosiasi/menalar. & $22-25$ \\
& Mengkomunikasin. & $26-31$ \\
& Penutup. & $32-35$ \\
\hline
\end{tabular}

Pengumpulan data dalam penelitian ini juga dilakukan dengan melakukan observasi langsung terhadap proses pembelajaran yang dilakukan guru. Berikut adalah kisi-kisi instrumen lembar observasi yang digunakan.

Tabel 3. Kisi-Kisi instrumen Observasi Pendekatan Ilmiah

\begin{tabular}{|c|c|c|}
\hline Tahapan Pembelajaran & $\begin{array}{ll}\text { Indikator } & \text { Penilaian } \\
\text { Pembelajaran } & \end{array}$ & $\begin{array}{l}\text { Nomor } \\
\text { Butir }\end{array}$ \\
\hline Kegiatan Pendahuluan & $\begin{array}{l}\text { Mempersiapkan peserta didik untuk } \\
\text { terlibat dalam pembelajaran }\end{array}$ & $1-5$ \\
\hline Kegiatan Inti: Penerapan & Mengamati & $6-11$ \\
\hline \multirow[t]{4}{*}{ Pendekatan Ilmiah } & Menanya & $12-15$ \\
\hline & Mengumpulkan informasi & $16-21$ \\
\hline & Mengasosiasi/Menalar & $22-25$ \\
\hline & Mengkomunikasikan & $26-31$ \\
\hline Penutup & Evaluasi dan tindak lanjut & $32-35$ \\
\hline
\end{tabular}

Teknik analisis data yang digunakan dalam penelitian ini adalah analisis persentase dan teknik analisis deskriptif. Analisis persentase dilakukan untuk mengetahui persentase perolehan setiap indikator yang menjadi fokus penelitian, sedangkan analisis deskriptif digunakan untuk mengetahui tingkatan capaian pelaksanaan pendekatan ilmiah dalam proses pembelajaran fisika. Berikut adalah persamaan yang digunakan secara berturut-turut untuk menentukan persentase perolehan dan tingkat pencapaian pelaksanaan pembelajaran fisika berbasis pendekatan ilmiah (scientific approach).

Persamaan penentuan persentase perolehan:

$$
\text { Persen Perolehah }=\frac{\text { Data Perolehan }}{\text { Jumlah Data }} \times 100 \%
$$


Sedangkan untuk mendeskripsikan tingkat pencapaian atau perolehan dilakukan dengan melakukan kategorisasi dengan mengadaptasi kriteria yang dikemukakan oleh Djemari Mardapi (2008). Alur yang digunakan adalah dengan cara menentukan skor minimum, skor maksimum, dan standar deviasi berdasarkan data yang diperoleh. Berikut adalah kategorisasi penilaian yang digunakan:

Tabel 4. Kategorisasi Penilaian

\begin{tabular}{ll}
\hline Skor & Kategori \\
\hline $\mathrm{Mi}+1,5 \mathrm{SBx}$ & Sangat Tingi/Sangat Positif \\
$\mathrm{Mi}+1,5 \mathrm{SBx}>\mathrm{X} \geq \mathrm{Mi}$ & Tinggi/Positif \\
$\mathrm{Mi} \geq \mathrm{X} \geq \mathrm{Mi}-1,5 \mathrm{SBx}$ & Cukup/Cukup Positif \\
$\mathrm{X}<\mathrm{Mi}-11,6 \mathrm{SBx}$ & Rendah/Negatif \\
\hline
\end{tabular}

Dengan:

$\mathrm{X}=\quad=$ skor aktual

$\mathrm{Mi}==$ Mean ideal $=1 / 2$ (skor tertinggi ideal + skor terendah ideal $)$

$\mathrm{SBx}==$ Simpangan baku ideal $=1 / 6$ (skor tetinggi ideal - skor terendah ideal)

Analisis korelasi dalam penelitian ini juga dilakukan guna mengetahui hubungan antara variabel-variabel yang menjadi aspek penelitian. Adapun variabel yang dikorelasikan dalam penelitian ini adalah persepsi peserta didik tentang proses pembelajaran yang dilakukan guru dengan pelaksanaan proses pembelajaran guru fisika. Data yang dikumpulkan merupakan data ordinal, sehingga teknik analisis yang digunakan adalah teknik analisis yang dikemukakan Spearman, dengan menggunakan bantuan program SPSS 16.

\section{HASIL DAN PEMBAHASAN}

Hasil

1. Karakteristik Responden

Responden dalam penelitian ini adalah 18 orang guru dan 494 peserta didik yang tersebar di 10 SMA Negeri. Berdasarkan hasil kuisioner, diketahui data jenjang pendidikan dari 18 guru yakni: terdapat empat orang guru dengan kualifikasi pendidikan S2 $(22.22 \%)$, tiga belas orang guru dengan kualifikasi pendidikan S1 $(72,22 \%)$ dan satu orang guru dengan kualifikasi D3 (5,56\%). Karakteristik peserta didik yang menjadi responden dalam penelitian ini diperoleh dari salah satu kelas yang menjadi subyek belajar dari guru yang menjadi subyek penelitian.

2. Persepsi Guru Terhadap Penerapan Pendekatan Ilmiah (Scientific Approach) Dalam Pembelajaran Fisika.

Berikut ditampilkan hasil analisis persepsi guru terhadap penerapan pendekatan ilmiah (scientific approach) dalam pembelajaran fisika. berdasarkan analisis masingmasing indikator.

Table. 5. Hasil analisis indikator persepsi guru terhadap penerapan pendekatan ilmiah (scientific approach).

\begin{tabular}{lcccc}
\hline Indikator Penilaian & \multicolumn{4}{c}{ Kategori Persepsi Guru (\%) } \\
\hline & Sangat Positif & Positif & Cukup Positif & Negatif \\
1. Persepsi Penerimaan & 94,44 & 5,56 & - & -
\end{tabular}


2. Persepsi Pelaksanaan Rata-Rata Persepsi Guru
83,33

90,97
16,67

9,03

Dari data diketahui sebaran persepsi guru terhadap penerapan pendekatan ilmiah dalam proses pembelajaran fisika. Hasil analisis indikator penerimaan diketahui 94,44\% (17 orang) guru menunjukkan respon yang sangat positif, sedangkan 5,56\% memberikan respon positif terkait dengan penerimaan penerapan pendekatan ilmiah. Indikator kedua, yakni persepsi guru terhadap pelaksanaan pendekatan ilmiah diketahui 83,33\% (15 orang) memiliki persepsi yang sangat positif untuk menerapkan pendekatan ilmiah dalam proses pembelajaran fisika, sedangkan 16,67\% (3 orang) memiliki persepsi yang positif untuk menerapkan pendekatan ilmiah dalam proses pembelajaran fisika. Hasil analisis secara keseluruhan dari kedua indikator diketahui 90,97\% (16 guru) memiliki persepsi yag sangat positif terhadap penerapan pendekatan ilmiah dalam proses pembelajaran fisika, sedangkan 9,03\% (2 orang) memiliki persepsi positif.

3. Persepsi Peserta Didik.

Angket persepsi peserta didik digunakan untuk mengetahui respon peserta didik terhadap proses pembelajaran yang dilakukan guru fisika. Data angket diperoleh dari 494 orang peserta didik yang tersebar di 10 SMA negeri tempat dilaksanakanya penelitian. Data persepsi peserta didik dianalisis dengan teknik kategorisasi dengan mengacu pada kriteria yang dikemukakan Mardapi (2010), dan teknik analisis persentase. Berikut ditampilkan data hasil angket persepsi peserta didik terhadap proses pembelajaran yang dilaksanakan oleh 18 orang guru fisika.

Tabel 6. Angket Persepsi Peserta Didik Terhadap Kemampuan Guru Melaksanakan Proses Pembelajaran Fisika.

\begin{tabular}{lll}
\hline Jumlah Guru & Perolehan Angket (\%) & Kategori \\
\hline 2 & 11,11 & Sangat Baik \\
14 & 77,78 & Baik \\
2 & 11,11 & Cukup Baik \\
- & - & Kurang Baik \\
\hline
\end{tabular}

Dari Tabel 6 di atas, diketahui 11,11\% (2 orang guru) melaksanakan proses pembelajaran dengan fisika dengan sangat baik, 77,78\% (14 orang guru) menurut penilaian peserta didik guru melaksanakan proses pembelajaran dengan baik, dan $11,11 \%$ (2 orang guru) yang menurut peserta didik cukup baik melaksanakan pembelajaran fisika.

4. Kemampuan guru Pelaksanaan pembelajaran

Untuk menilai kemampuan guru fisika melaksanakan pembelajaran fisika berbasis pendekatan ilmiah (scientific approach), dilakukan melalui observasi langsung. Rangkuman hasil observasi kemampuan guru melaksanakan pembelajaran fisika berbasis pendekatan ilmiah (scientific approach) dapat dilihat pada tabel berikut ini. Tabel 7. Rangkuman Kemampuan Guru Fisika Melaksanakan Pembelajaran Fisika Berbasis Pendekatan Ilmiah (Scientific Approach)

\begin{tabular}{lll}
\hline Jumlah Guru & Perolehan Kemampuan Guru (\%) & Kategori \\
\hline 3 & 16,67 & Sangat Baik \\
7 & 38,89 & Baik
\end{tabular}




\begin{tabular}{lll}
\hline Jumlah Guru & Perolehan Kemampuan Guru (\%) & Kategori \\
\hline 8 & 44,44 & Cukup Baik \\
- & - & Kurang Baik \\
Rata-Rata & 70 & Baik \\
\hline
\end{tabular}

Berdasarkan data Tabel 7, diketahui sebanyak 3 orang guru (16,67\%) dari 18 guru fisika mampu melaksanakan pembelajaran dengan sangat baik, 7 orang guru $(38,89 \%)$ melaksanakan pembelajaran fisika dengan baik, dan 8 orang gru fisika $(44,44 \%)$ guru melaksanakan pembelajaran dengan kategori cukup baik. Sedangkan hasil analisis secara keseluruhan, diketahui guru fisika SMA Negeri Kota Yogyakarta rata-rata mampu melaksanakan pembelajaran dengan baik, dengan persentase sebesar $70 \%$.

5. Analisis hubungan persepsi peserta didik terhadap proses pembelajaran dengan kemampuan guru.

Hasil analisis korelasi antara variabel persepsi peserta didik dengan kemampuan guru melaksanakan pembelajaran fisika berbasis pendekatan ilmiah (scientific approach), ditunjukkan pada Tabel 8 di bawah ini.

Tabel 8. Hubungan Persepsi Peserta Didik Terhadap Proses Pembelajaran Dengan Kemampuan Guru.

Nonparametric Correlations

Kemampua Persepsi Siswa nGuru

Spearman's rho Kemampuan Guru Correlation $1.000 \quad 0,491^{*}$

Coefficient

Sig. (2-tailed) $\quad 0,038$

$\begin{array}{lll}N & 18 & 18\end{array}$

*. Correlation is significant at the 0.05 level (2-tailed).

Berdasarkan Tabel 8 di atas, diketahui diketahui kemampuan guru dan persepsi siswa berkorelasi positif dengan nilai koefisien korelasi sebesar 0,491 dan taraf signifikan 0,038. Hasil ini menunjukkan ada hubungan antara variabel persepsi peserta didik dengan dengan kemampuan guru.

\section{Pembahasan}

1. Persepsi Guru Fisika Terhadap Penerapan Pendekatan Ilmiah (Scientific Approach).

Guru adalah aspek utama yang memegang peran penting dan penentu gerak majunya pendidikan, subyek pelaksana dari suatu kebijakan pendidikan, sehingga berhasil tidaknya suatu program pendidikan, kurikulum pembelajaran, sebagian besar ditentukan kesiapan guru untuk melaksanakan. Persepsi guru terhadap kebijakan pendidikan merupakan salah satu aspek yang mempengaruhi performance guru dalam melaksanakan tugas-tugas pengajaran dan tugas non mengajar. Menurut Middleton (Depdiknas, 2008), keberhasilan suatu program pendidikan ditentukan sangat ditentukan oleh persepsi guru, yakni bagaimana pandangan dan penerimaan guru terhadap program tersebut. Guru dengan persepsi yang positif akan lebih mudah menerima dan melaksanakan perubahan 
kebijakan. Pentingnya guru memiliki persepsi yang positif juga disampaikan Sumidi (2005), bahwa kinerja, motivasi dan komitmen guru untuk bekerja dalam melaksanakan tugas-tugas guru dipengaruhi oleh persepsi dan pandangan guru terhadap program pendidikan tersebut. Selain itu Bernaus, Gardner (2009) dan Adeyemo (2011) juga menyatakan hal yang sama tentang besarnya pengaruh persepsi guru. Disampaikan bahwa persepsi guru berpengaruh dan memainkan peran penting terhadap motivasi dan keberhasilan peserta didik dalam belajar. Hal ini tidak lain karena guru merupakan individu yang berhadapan langsung dengan peserta didik dan yang memberikan instruksi langsung kepada peserta didik.

Berdasarkan fokus penelitian, terdapat dua komponen penilaian yang digunakan untuk menilai persepsi guru terhadap penerapan pendekatan ilmiah, yakni: Penerimaan terhadap penerapan pendekatan ilmih dalam proses pembelajaran fisika dengan indikator utama penyusunan RPP dan komponen pelaksanaan pembelajaran fisika dengan tiga indikator utama, yakni kegiatan pendahuluan, kegiatan inti dan kegiatan penutup. Berdasarkan hasil analisis diketahui 94,44\% dari 18 guru yang menjadi subyek penelitian menunjukkan persepsi atau pandangan yang sangat positif diterapkannya pendekatan ilmiah dalam proses pembelajaran fisika, sedangkan 5,56\% dari 18 guru subyek penelitian menunjukkan persepsi yang positif dengan diterapakannya pendekatan ilmiah (scientific approach) dalam proses pembelajaran fisika.

Besarnya tingkat persentase persepsi guru terhadap pembelajaran dengan pendekatan ilmiah dapat dideskripsikan karena konsep pendekatan ilmiah yang diterapkan pada kurikulum 2013 secara umum memiliki kesamaan dengan konsep pembelajaran fisika yang mengedepankan pada bentuk-bentuk pembelajaran melalui kegiatan pengamatan (observasi), kegiatan percobaan, hingga penarikan kesimpulan berdasarkan hasil pembuktian. Diketahui bahwa pembelajaran fisika merupakan pembelajaran yang mengedepankan pada kegiatan-kegiatan demonstrasi, ekperimen, dan apabila bentuk-bentuk kegiatan tersebut dipadukan dengan pendekatan ilmiah, dapat disimpulkan pada dasarya pendekatan ilmiah (scientific approach) dalam proses pembelajaran fisika bukan merupakan hal baru, hal inilah yang mendasari tingginya sikap positif guru fisika dengan diterapkkanya pendekatan ilmiah dalam setiap proses pembelajaran fisika. Guru fisika secara umum tidak kesulitan melaksanakan pembelajaran dengan menggunakan tahaptahap dari pendekatan ilmiah.

Pentingnya guru memiliki persepsi yang positif terhadap suatu program pendidikan ditunjukkan oleh hasil penelitian yang dilakukan oleh Subede (2017) bahwa guru dengan persepsi positif cenderung memiliki kemampuan yang baik dalam melaksanakan proses pembelajaran dan lebih procedural dalam menerapkan kurikulum 2013. Dengan demikian, berkaiatan dengan hasil persepsi guru dan penelitian yang dilakukan oleh Subede, dapat disimpulkan bahwa persepsi guru terhadap program pendidikan, program pembelajaran berpengaruh terhadap kompetensi dan kemampuan guru melaksnakan program tersebut. Semakin positif persepsi yang dimiliki guru, semakin memudahkan guru untuk menerapkan kebijakan tersebut, karena persepsi yang positif memberikan motivasi eksernal tersebut bagi guru tersebut. 


\section{Persepsi Peserta Didik Terhadap Proses Pembelajaran Fisika.}

Peserta didik merupakan salah satu bagian penting dalam proses pendidikan. Keberadaan peserta didik, proses belajar mengajar dapat berlangsung, baik dalam lingkup pendidikan formal maupun pendidikan non formal. Kontribusi dari persepsi peserta didik terhadap pengajaran dan pembelajaran sangat besar yakni persepsi peserta didik dapat dijadikan sebagai sarana bagi guru dalam melakukan perbaikan kedepannya (Ampadu, 2012). Pernyataan ini menggambarkan persepsi dari peserta didik memiliki manfaat tersendiri dalam perbaikan proses belajar. Ampadu dan Carvalho (2011) kemudian merekomendasikan agar persepsi peserta didik dapat digunakan sebagai alat evaluasi proses pembelajaran, dan sebagai alat evaluasi untuk meningkatkan efektivitas mengajar dan mengembangkan konsepkonsep baru yang sesuai tujuan kurikuler. Persepsi peserta didik termasuk kedalam kelompok persepsi sosial-psikologi, yaitu cara peserta didik memberikan tafsiran terhadap situasi dan lingkungan yang berkaitan dengan pembelajaran. Proses pembelajaran dapat berlangsung efektif bila persepsi peserta didik menunjang proses pembelajaran (Surya, 2013).

Persepsi peserta didik dalam penelitian ini adalah pandangan yang dimiliki peserta didik terhadap pelaksanaan pembelajaran yang dilakukan guru. Dari hasil diketahui: $11,11 \%$ peserta didik menyatakan guru melaksanakan proses pembelajaran fisika dengan sangat baik, 77,78\% menyatakan guru fisika melaksanakan proses pembelajaran fisika dengan baik, dan 11,11\% peserta didik menilai bila guru melaksanakan pembelajaran fisika berbasis pendekatan ilmiah dengan cukup baik.

Berdasarkan data tersebut, diketahui secara umum guru fisika di SMA Negeri Kota Yogyakarta melaksanakan pembelajaran dengan baik. Hal ini menunjukkan guru fisika secara umum mampu menerapkan pendekatan ilmiah dalam proses pembelajaran fisika dengan baik. Hasil analisis dari tujuh indikator persepsi peserta didik yang meliputi indikator kegiatan pendahuluan, kegiatan mengamati, kegiatan menanya, kegiatan menalar, mencoba, mengkomunikasikan, dan penutup, terdapat dua indikator yang menurut peserta didik terlaksana dengan sangat baik, yakni indikator pertama (kegiatan pendahuluan) dan indikator ketiga kegiatan menanya dengan persen perolehan $80 \%$ dan $81 \%$. Sedangkan 5 indikator lain terlaksana dengan kategori baik dengan persentase rata-tata sebesar $74 \%$.

Yang menarik dari keseluruhan item persepsi peserta didik, terdapat beberapa item yang menurut peserta didik jarang dilakukan guru. Item-item tersebut adalah: 1) guru jarang memberikan kesempatan kesempatan kepada peserta didik untuk menjelaskan kembali materi yang telah dipelajari (71\%); 2 guru jarang memberikan kesempatan kepada peserta didik menjelaskan kembali tahapan-tahapan penyelesaian dari tugas yang diberikan (61\%).

Item pernyataan lain yang juga menurut peserta didik jarang dilakukan adalah penjelasan manfaat langsung maupun tidak langsung dari materi yang dipelajari (44\%), dan guru jarang menginformasikan rencana kegiatan untuk pertemuan selanjutnya (39\%). Kegiatan yang sering dilakukan oleh guru adalah yakni: 1) penjelaskan terhadap cakupan materi yang akan dipelajari; 2) pemberian kesempatan kepada peserta didik untuk mempelajari materi yang sedang dibahas; 3) memberikan kesempatan kepada peserta didik untuk bertanya terkait 
demonstrasi dan materi yang dipelajari; 4) guru sering memberikan tugas, baik tugas individu maupun tugas kelompok.

Berdasarkan persepsi peserta didik, diketahui terdapat beberapa poin mendasar yang sekiranya dapat ditingktkan oleh guru, yakni menjelaskan tujuan pembelajaran. Pentingnya tujuan pembelajaran disampaikan oleh Resti Fauziah, dkk (2013) bahwa tujuan pembelajaran yang disampaikan dengan baik berpengaruh terhadap kegiatan pembelajaran dan aktivitas peserta didik dalam mengikuti kegiatan belajar mengajar. Pada kegiatan penuutp, aspek yang perlu menadapat perhatian guru adalah penjelasan manfaat langsung maupun tidak langsung dari materi yang dipelajari. Penjelasan ini penting mengingat pada awal pembelajaran guru menyampaikan tujuan pembelajaran, selai itu peserta ddik dapat mengetahui manfaat dari materi yang telah dipelajari. Hal lain yang juga perlu mendapat perhatian dari guru adalah menginformasikan rencana kegiatan untuk pertemuan berikutnya. Informasi ini penting bagi peserta didik untuk dapat mempersiapkan diri sebelum mengikuti materi selanjutnya, dan bagi guru dapat memudahkan penyampaian materi karena telah dipelajari sebelumnya oleh peserta didik.

3. Kemampuan Melaksanakan Pembelajaran Fisika.

Kemampuan guru melaksanakan pembelajaran fisika berbasis pendekatan ilmiah (scientific approach) diperoleh dengan melakukan pengamatan langsung saat kegiatan belajar mengajar. Dari hasil analisis penilaian kemampuan melaksanakan pembelajaran, diketahui $16,67 \%$ guru melaksanakan pembelajaran dengan sangat baik, 38,89\% melaksanakan pembelajaran dengan baik, dan 44,44\% melakanakan pembelajaran dengan cukup baik. Sedangkan hasil analisis secara keseluruhan diketahui proses pembelajaran fisika berbasis pendekatan ilmiah (scientific approach) di SMA Negeri Kota Yogyakarta telah terlaksana dengan baik.

Beberapa hal yang ditemukan saat observasi, guru jarang menjelaskan tujuan pembelajaran kepada peserta didik. Selain itu guru jarang menggunakan media yang menarik perhatian peserta didik, baik media visual maupun melalui demontrasi sederhana. Guru belum menentukan aspek-aspek yang perlu diamati, baik data primer maupun data sekunder. Guru juga belum mengaktifkan peserta didik untuk bertanya dan mengungkapkan pendapat. Item yang juga jarang dilakukan adalah pemberian kesempatan kepada peserta untuk merangkum dan menjelaskan kembali materi yang telah dipelajari, serta tidak dijelaskannya manfaat langsung maupun tidak langsung dari materi yang dipelajari. Hasil pengamatan ini sejalana dengan pendapat peserta didik jika terdapat beberapa kegiatan utama yang mendukung pembelajaran aktif jarang dilakukan guru.

Dari temuan tersebut, diketahui proses pembelajaran belum sepenuhnya mencerminkan kaidah-kaidah ilmiah. Guru lebih banyak mengarahkan peserta didik untuk mengerjakan soal dalam mengukur pemahaman peserta didik. Dari hasil pengamatan, peserta didik menjadi kesulitan ketika diberikan soal baru, hal ini dikarenakan pembelajaran dibangun dengan memberikan rumus atau persamaan matematika untuk dihafalkan tanpa menjelaskan konsep yang ada pada persamaan. Keterlibatan dan keaktifan peserta didik perlu menjadi perhatian guru, karena salah satu tujuan dari pembelajaran berbasis pendekatan ilmiah (scientific approach) adalah peserta didik dapat terlibat secara aktif untuk mengkonstruksi 
sendiri pengetahuannya. Hasil penelitian yang dilakukan oleh Resti Fauziah, dkk (2013) juga memberikan gambaran bahwa guru dapat melaksanakan proses pembelajaran berbasis pendekatan ilmiah bilamana telah direncanakan dengan baik, karena secara konsep dan praktek, penggunaan pendekatan ilmiah dapat meningkatkan keterlibatan dan aktivitas peserta didik dengan melakukan persiapan sebelum memulai pembelajaran harus siap dengan wawasan materi yang selalu berkembang.

4. Hubungan Persepsi Peserta Didik Dengan Kemampuan Guru.

Hasil analisis menunjukkan hubungan yang positif antara persepsi peserta didik dengan kemampuan guru dalam mengimplemantasikan pembelajaran fisika berbasis pendekatan ilmiah (scientific approach). Hubungan kedua variabel tersebut ditunjukan oleh nilai koefisien korelasi sebesar 0,499 dengan derajad signifikan 0,035. Artinya persepsi yang dimiliki peserta didik dipengaruhi oleh kemampuan guru melaksanakan pembelajaran. Semakin baik kemampuan guru melaksanakan proses pembelajaran, persepsi peserta didik juga akan memiliki persepsi yang baik.

Hasil penelitian ini sejalan dengan hasil penelitian yang dilakukan Bernaus dan Gardner (2008) yang menunjukkan bagaimana strategi pembelajaran yang digunakan guru mempengaruhi persepsi peserta didik dalam belajar. Penelitian penelitian yang dilakukan Lin, Hen, Chau Jeng, dan Huang (2010) juga menunjukkan hal yang sama yakni terdapat hubungan yang positif antara kualitas mengajar dan strategi mengajar dengan persepsi peserta didik. Selain itu, penelitian yang dilakukan Adeyemo (2011) juga menunjukkan hubungan yang signifikan antara persepsi peserta didik dan persepsi guru terhadap kemampuan akademik peserta didik. Sehingga dapat disimpulkan kemampuan dan kualitas guru dalam mengajar, baik dalam dalam menggunakan strategi pembelajaran, pengelolaan kelas, dan penggunaan media mempengaruhi persepsi peserta didik terhadap proses pembelajaran.

Berkaitan dengan persepsi peserta didik, Kunandar (2013), Ampadu (2012), Carvalho (2011) merekomendasikan agar guru dapat memanfaatkan persepsi peserta didik sebagai bahan refleksi dan bahan evaluasi dari proses pembelajaran yang telah dilakukan. Baik tidaknya persepsi yang peserta didik, dapat dijadikan sebagai bahan untuk melakukan perbaikan dan peningkatan kualitas mengajar.

\section{KESIMPULAN}

Berdasarkan data yang telah dikumpulkan, analisis data, dan pembahasan, maka disimpulkan: 1) Guru fisika SMA Negeri Kota Yogyakarta memiliki persepsi yang sangat positif diterapkannya pendekatan ilmiah dalam proses pembelajaran fisika; 2) Peserta didik SMA Negeri Kota Yogyakarta menilai bahwa guru fisika telah melaksanakan proses pembelajaran fisika berbasis pendekatan ilmiah dengan baik; dan 3) Terdapat hubungan yang positif dan signifikan antara persepsi peserta didik dengan kemampuan guru melaksanakan pembelajaran fisika berbasis pendekatan ilmiah (scientific approach).

\section{IMPLIKASI}

Hasil penelitian ini secara umum akan memberi kontribusi positif yang berupa stimulus bagi guru untuk melakukan evaluasi secara berkala, baik dari aspek membuat perencanaan, pelaksanaan, maupun dalam peningkatkan kapasitas 
profesionalime, serta dapat menjadikan peserta didik sebagai evaluator untuk meningkatkan kualitas pembelajaran dengan memahami keinginan atau persepsi peserta didik terlebih dahulu.

Hasil penelitian ini juga dapat menjadi titik tolak bagi guru, sekolah dan dinas pendidikan untuk melakukan perbaikan dalam peningkatan kapasitas dan kapabilitas guru sebagai tenaga pendidik. Harus diakui guru merupakan ujung tombak pendidikan, di mana peserta didik sebagai sasaran pendidikan, namun dengan memperhatikan masukan atau persepsi peserta didik, akan terbuka kesempatan yang lebih luas dalam menghantarkan peserta didik untuk mencapai pengetahuan yang maksimal.

\section{SARAN}

Berdasarkan hasil penelitian dan kesimpulan di atas, untuk meningkatkan kualitas pembelajaran yang berlandaskan pada kaidah-kaidah ilmiah, khususnya pada mata pelajaran fisika, maka disampaikan beberapa saran berikut:

1. Bagi guru. Diharapkan guru dapat menggunakan persepsi peserta didik sebagai salah satu bentuk penilaian untuk melakukan evaluasi terhadap proses pembelajaran yang telah dilakukan. Dalam menyusun perangkat pembelajaran, hendaknya perngkat pembelajaran dibuat lebih lengkap yang dapat mencerminkan tujuan yang akan dicapai, dan kiranya dalam menyususn perangkat pembelajaran, dapat dilakukan setiap akan melakukan pembelajaran, tidak disusun sekaligus untuk pertemuan dalam satu semester. Guru dapat melakukan evaluasi terhadap pembelajaran yang telah dilakukan dengan menilai tingkat keberhasilan dari pembelajaran. Guru dapat lebih memberikan kesempatan kepada peserta didik dalam kegiatan pembelajaran yang dapat dilakukan dengan merancang suatu strategi yang dapat mengaktifkan peserta didik.

2. Bagi kepala sekolah hendaknya dapat mengevaluasi kegiatan guru, baik berkaitan dengan penyusunan RPP, maupun pelaksanaan pembelajaran, serta dapat menjadikan faktor persepsi peserta didik sebagai masukan yang baik bagi pengembangan pembelajaran di sekolah.

3. Bagi Dinas Pendidikan, diharapkan dapat melakukan pelatihan bagi guru untuk melaksanakan 1pembelajaran dengan memanfaatkan media pembelajaran, pelatihan pentingnya penyusunan RPP dan pelatihan untuk melaksanakan pembelajaran yang berbasis tujuan.

\section{DAFTAR PUSTAKA}

(2007). Naska Akademik Kajian Kebijakan Kurikulum Mata Pelajaran IPA. Jakarta: Pusat Kurikulum.

(2009). Teachers' Motivation, Classroom Strategy Use, Students' Motivation and Second Language Achievement. Porta Linguarum, 25-36.

Adeyemo, S. A. (2011). The Effect of Teachers' Perception and Students' Perception of Physics Classroom Learning Environment on their Academic Achievement in Senior Secondary Schools Physics. International Journal of Educational Research and Technology, 2 (1), 74-81. 
Ampadu, E. (2012). Students' Perceptions of their Teachers' Teaching of Mathematics: The Case of Ghana. International Online Journal of Educational Sciences, 4(2), 351-358.

Bernaus, M., \& Gardner, R. C. (2008). Teacher Motivation Sttrategies, Student Perception, Student Motivations, and English Achievent. The Modern Language Jounal, 92(3), 387-401.

Carvalho, C., Freire, s., Conboy, J., Babtista, M., Freire, A., Azevedo, M., et al. (2011). Student Perceptions of Secondary Science Teacher's Practices Following Curricular Change. Jurnal of Turkish Science Education, 8(1), 29-41.

Depdiknas. (2008). Kajian Kebikajakan Kurikulum Sekolah Menengah. Jakarta: Puskur.

Fauziah, Resti. Abdullah, Ade Gafar. Hakim, Dadang Lukman. (2013). Pembelajaran Saintifik Elektronika Dasar Berorientasi Pembelajaran Berbasis Masalah. INVOTEC. 9(2), 165-178.

Kemendiknas. (2010). Sejarah Pusat Kurikulum. Jakarta: Puskur: Badan Penelitian dan Pengembangan.

Kunandar. (2013). Penilaian Autentitik Penilaian Hasil Belajar Peserta Didik Berdasarkan Kurikulum 2013. Jakarta: Rajawali Pers.

Lin, R., Hen, J., Chau Jeng, Y., \& Huang, S. (2010). The Relationship between Teacher Quality and Teaching Effectiveness Perceived by Students from Industrial Vocational High Schools. Asian Journal of Arts and Sciences, 2 (1), 167-187.

Mardapi, D. (2008). Teknik Penyusunan Instrumen Tes dan Nontes. Yogyakarta: Mitra Cendekia Offset.

Mendikbud. (2013). Permendikbud Nomor 65 Tahun 2013 Tentang Standar Proses Pendidikan Dasar dan Menengah.

Subede, Ade Listanti (2017). Persepsi Guru Bahasa Inggris Terhadap Penerapan Kurikulum 2013. Thesis. Universitas Negeri Makasar.

Suluh, M. (2018). Perspektif Pendidikan Nasional. Jurnal Penelitian dan Pengkajian Ilmu Pendidikan: e-Saintika, 2(1), 1-9.

Surya, M. (2013). Psikologi Guru Konsep dan Aplikasi dari Guru, untuk Guru. Bandung: Alfabeta. 